\title{
Campylobacter volucris sp. nov., isolated from black-headed gulls (Larus ridibundus)
}

\author{
Lies Debruyne, ${ }^{1} \dagger$ Tina Broman, ${ }^{2}$ Sven Bergström, ${ }^{3}$ Björn Olsen, ${ }^{4}$ \\ Stephen L. W. On ${ }^{5} \ddagger$ and Peter Vandamme ${ }^{1}$
}

Correspondence

Lies Debruyne

Lies.Debruyne@ilvo.vlaanderen.be

\author{
${ }^{1}$ Department of Biochemistry, Physiology and Microbiology, Faculty of Sciences, Ghent University, \\ Ledeganckstraat 35, B-9000 Gent, Belgium \\ ${ }^{2}$ CBRN Defence and Security, FOI, Swedish Defence Research Institute, SE-901 82 Umeå, \\ Sweden \\ ${ }^{3}$ Department of Molecular Biology, Umeå University, SE-901 87 Umeå, Sweden \\ ${ }^{4}$ Department of Medical Sciences, Section of Infectious Diseases, Uppsala University Hospital, \\ SE-751 85 Uppsala, Sweden \\ ${ }^{5}$ Danish Institute of Food and Veterinary Research, DK-1790 Copenhagen, Denmark
}

The genus Campylobacter, belonging to the class Epsilonproteobacteria, was proposed by Sebald \& Véron (1963) to accommodate two Vibrio-like species, currently known as Campylobacter fetus and Campylobacter sputorum. The genus has expanded steadily since then and, at the time of writing, comprises 21 species and 8 subspecies (Debruyne et al., 2008, 2009; Rossi et al., 2009; Zanoni et al., 2009). Over the years, a strong association has been demonstrated between certain Campylobacter species and birds, both domesticated and wild. Some of these Campylobacter species, like Campylobacter canadensis, have so far been isolated solely from birds (Inglis et al., 2007), while others, like Campylobacter jejuni, can be found in avian and human and other mammalian sources (Broman

tPresent address: Institute for Agricultural and Fisheries Research Social Sciences Unit, Burg. van Gansberghelaan 115, Box 2, B-9820 Merelbeke, Belgium.

$\ddagger$ Present address: Institute of Environmental Research and Science, Food Safety Programme, PO Box 29 181, Christchurch, New Zealand.

The GenBank/EMBL/DDBJ accession numbers for the 16S rRNA and hsp60 gene sequences of strains LMG 24379, LMG $24380^{\top}$ and LMG 24381 are FM883693-FM883695 (16S rRNA gene) and FM883696FM883698 ( $h s p 60$ ), respectively.

Dendrograms based on AFLP fingerprints and whole-cell protein SDSPAGE profiles and a table of differential properties for the novel species and all members of Campylobacter are available as supplementary material with the online version of this paper. et al., 2002, 2004; Petersen et al., 2001; Waldenström et al., 2002 , 2007). The isolation of campylobacteria from wild birds, including species that are zoonotic enteropathogens, indicates that wild birds potentially serve as a reservoir for human infection. A limited number of studies have focused on this epidemiological aspect, in particular for C. jejuni. One report describes the isolation from wild peregrine falcons in Sweden in 2000 of two C. jejuni isolates that shared identical PFGE patterns with an isolate obtained from a young man in southern Sweden in 1999 (Palmgren et al., 2004). Genotyping by multilocus sequence typing (Colles et al., 2009; French et al., 2009) and PFGE (Broman et al., 2002, 2004) of a large selection of $C$. jejuni isolates, originating from wild birds, domestic animals and humans, showed that strains isolated from wild birds are most often different from clinical strains but that similarities occur in some cases, notably in birds strongly associated with human activities. Other studies also seem to indicate that wild animals and birds carry their own, host-speciesadapted Campylobacter populations, distinct from those found in domesticated animals and humans (Petersen et al., 2001; Waldenström et al., 2007).

Black-headed gulls (Larus ridibundus) belong to the ecological guild of the opportunistic feeders, a group that was reported to be among the ecological guilds of birds most commonly infected by campylobacteria (Waldenström et al., 
2002). They are omnivorous and feed in natural habitats, as well as in farmland and urban surroundings. During a study on the prevalence of $C$. jejuni in this bird species in southern Sweden (Broman et al., 2002), three strains, originating from three individual birds, were isolated that gave a negative reaction in the $C$. jejuni/C. coli multiplex PCR (Vandamme et al., 1997) that was used for species identification. Subsequently, these isolates were subjected to 23 S rRNA PCR-RFLP (Fermer \& Engvall, 1999) and were identified as Campylobacter lari. During a large-scale investigation of the diversity of $C$. lari-like bacteria, these three isolates formed a distinct group, by both whole-cell protein SDS-PAGE and AFLP analysis. In the present study, their unique position was further examined by determination of phenotypic characteristics, $16 \mathrm{~S}$ rRNA and hsp60 gene sequence analysis and DNA-DNA hybridizations.

Details of the sampling procedure were described previously (Broman et al., 2002). Sampling was performed in Malmö, southern Sweden, in March 1999. Birds were sampled by insertion of a sterile swab in the cloaca, and each swab was placed in Amies charcoal transport medium (Transwab; BioDisc) and cultured within $24-72 \mathrm{~h}$ of sampling. The samples were plated onto Campylobacter selective medium, consisting of $\left(1^{-1}\right) 42.5 \mathrm{~g}$ Columbia blood agar base (Acumedia Manufacturers), $5 \%$ defibrinated horse blood, $10 \mathrm{mg}$ vancomycin, $2500 \mathrm{IU}$ polymyxin $\mathrm{B}$ and $5 \mathrm{mg}$ trimethoprim, and incubated at $42{ }^{\circ} \mathrm{C}$ under microaerobic $\left(5 \% \mathrm{O}_{2}, 10 \% \mathrm{CO}_{2}, 85 \% \mathrm{~N}_{2}\right)$ conditions. The plates were checked for Campylobacter-like growth after 24 and $48 \mathrm{~h}$ of incubation. From each plate with growth of suspected campylobacters, one colony was subcultured on blood-agar plates and investigated further. Isolates were stored at $-80{ }^{\circ} \mathrm{C}$ in trypticase soy broth (BD) supplemented with $15 \%$ glycerol.

Strains were subsequently cultured on Mueller-Hinton agar (Oxoid), supplemented with $5 \%$ sterile horse blood, and incubated at $37{ }^{\circ} \mathrm{C}$ for $48 \mathrm{~h}$ under microaerobic conditions. DNA was extracted as described by Pitcher et al. (1989).

AFLP analysis was performed as described previously (Debruyne et al., 2009). In brief, $1 \mu \mathrm{g}$ genomic DNA was digested with the restriction enzyme combination HindIII/ HhaI, after which site-specific adapters were ligated to the restriction fragments. Primers complementary to the adaptor and restriction site sequence were used in subsequent preselective and selective PCR amplification reactions. The amplified and fluorescently labelled fragments were loaded on a denaturing polyacrylamide gel on an ABI Prism 377 automated sequencer. GENESCAN version 3.1 (Applied Biosystems) was used for data collection, and the generated profiles were imported, using the CrvConv filter, in BioNumerics version 4.61 (Applied Maths) for normalization and further analysis. After normalization, the AFLP profiles were imported into an in-house AFLP reference database that contains profiles from type and reference strains of all established Campylobacter species.
The similarity between profiles was determined by Pearson's correlation coefficient, and cluster analysis was performed by the unweighted pair group method with arithmetic means (UPGMA). AFLP profiles of the three isolates representing the distinct taxon were divergent from those of other $C$. lari-like strains and all other Campylobacter species (Supplementary Fig. S1, available in IJSEM Online).

This divergence was supported by whole-cell protein SDSPAGE analysis. Protein extraction and SDS-PAGE were performed as described by Pot et al. (1994). Similarity of the obtained normalized SDS-PAGE patterns was determined by Pearson's correlation coefficient, and clustering was performed by UPGMA, using BioNumerics version 4.61. For numerical analysis, a variable region of dense bands (36.1-43.2 kDa) (Vandamme et al., 1990) was excluded to increase species discrimination. The results of the numerical analysis, in combination with visual inspection of the SDS-PAGE patterns, demonstrated that the SDS-PAGE patterns of the three novel strains were distinct from those of $C$. lari and of all other known Campylobacter species (Supplementary Fig. S2).

To determine the phylogenetic position of this taxon, $16 \mathrm{~S}$ rRNA and $h s p 60$ gene sequences of isolates LMG 24379, LMG $24380^{\mathrm{T}}$ and LMG 24381 were generated. $h s p 60$ gene sequences were determined as they offer improved resolution compared with 16S rRNA gene sequences (Kärenlampi et al., 2004). 16S rRNA gene sequences were determined as described previously (Vandamme et al., 2006). Sequences were assembled using BioNumerics version 5.1, and all three strains had identical 16S rRNA gene sequences. Comparison by the megaBLAST algorithm to the GenBank sequence database revealed that the nearest phylogenetic neighbours were $C$. lari subsp. concheus, $C$. lari subsp. lari, C. jejuni, C. coli, Campylobacter insulaenigrae, Campylobacter peloridis and Campylobacter subantarcticus, all with similarity levels exceeding $97 \%$. For tree reconstruction, sequences were aligned using the CLUSTAL_X software package (Thompson et al., 1997), and clustering was performed by the neighbour-joining method (Saitou \& Nei, 1987) using BioNumerics version 5.1. Unknown bases were discarded for the analysis. Bootstrap values were determined using 500 replicates (Fig. 1). Partial hsp60 gene sequencing was performed as described previously (Debruyne et al., 2009), and further analysis was performed as for the 16S rRNA gene sequences (Fig. 2). The three isolates representing the novel taxon shared identical $h s p 60$ gene sequences ( $100 \%$ sequence similarity), while interspecific sequence similarities were no higher than $93.7 \%$.

Over 60 phenotypic characteristics were determined using an array of well-standardized methods described previously (On et al., 1996). Results were compared with those for other Campylobacter species, and an overview of the differentiating characteristics between the novel species and its nearest phylogenetic neighbours (as determined by 16S rRNA gene sequence analysis) is provided in Table 1. 


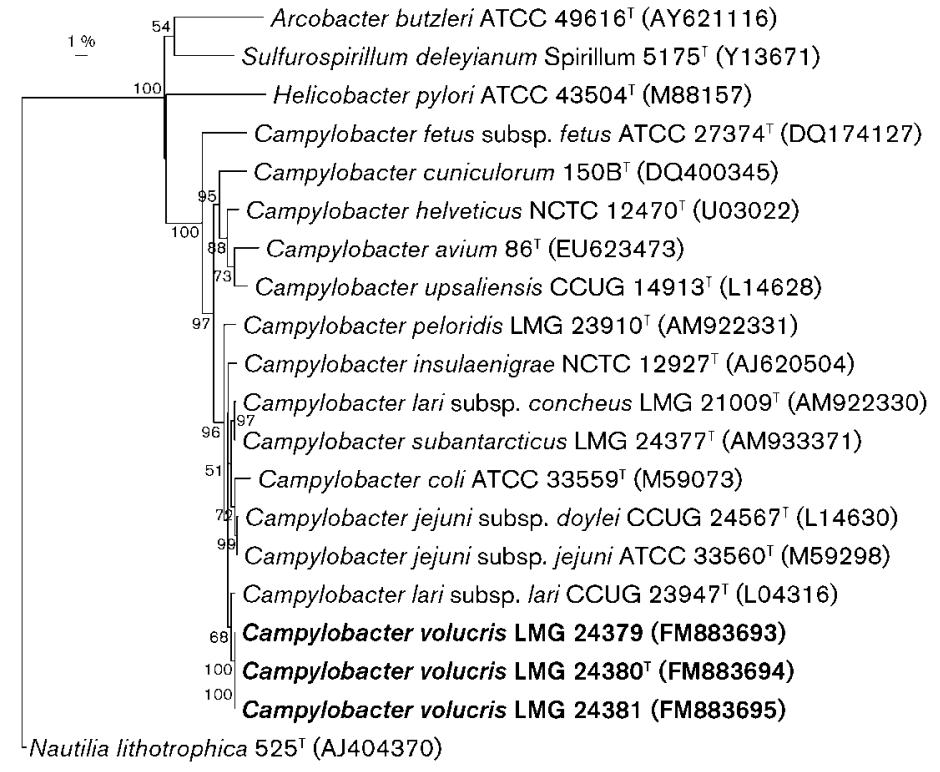

Fig. 1. Phylogenetic tree based on $16 \mathrm{~S}$ rRNA gene sequences constructed by the neighbour-joining method. Bootstrap values (\%) are indicated at nodes. Bootstrap values lower than $50 \%$ are not shown. Bar, $1 \%$ sequence divergence.
Characteristics that allow the differentiation of the novel species from all other Campylobacter species are presented in Supplementary Table S1. The novel species only differs by a single phenotypic characteristic from both Campylobacter lanienae (resistance to cefoparezone) and $C$. canadensis (resistance to cephalothin). However, they can be readily distinguished by whole-cell protein SDS-PAGE analysis or by analysis of the AFLP patterns.

For the determination of $\mathrm{G}+\mathrm{C}$ content, DNA was enzymically degraded into nucleosides as described by Mesbah \& Whitman (1989). The nucleoside mixture was separated by HPLC using a Waters SymmetryShield C8 column maintained at $37{ }^{\circ} \mathrm{C}$. The solvent was $0.02 \mathrm{M}\left(\mathrm{NH}_{4}\right) \mathrm{H}_{2} \mathrm{PO}_{4}$ $(\mathrm{pH} 4.0)$ with $1.5 \%$ acetonitrile. Non-methylated $\lambda$ phage
DNA (Sigma) was used as the calibration reference. The DNA G + C content of strain LMG $24380^{\mathrm{T}}$ was $29 \mathrm{~mol} \%$, which falls just within the range reported for the genus Campylobacter (29-47 mol\%; Debruyne et al., 2008). An overview of $\mathrm{G}+\mathrm{C}$ contents for Campylobacter species is given in Supplementary Table S1.

DNA-DNA hybridizations were performed between strain LMG $24380^{\mathrm{T}}$ and the type strains of its closest relatives. DNA was extracted from $0.25-0.5 \mathrm{~g}$ (wet weight) cells as described by Pitcher et al. (1989). DNA-DNA hybridizations were performed with photobiotin-labelled probes in microplate wells (Ezaki et al., 1989), using an HTS7000 Bio Assay Reader (Perkin Elmer) for the fluorescence measurements. The hybridization temperature was $30{ }^{\circ} \mathrm{C}$.

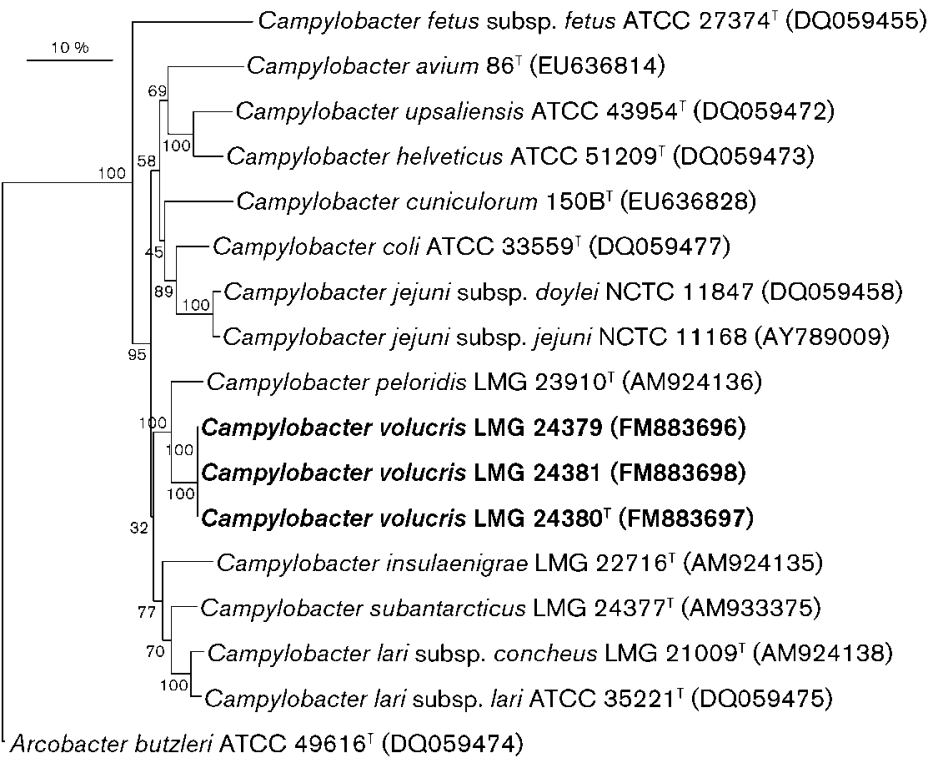

Fig. 2. Neighbour-joining tree based on partial $h s p 60$ gene sequences. All sequences were $555 \mathrm{bp}$ in length, with the exception of the sequences for C. cuniculorum $150 \mathrm{~B}^{\top}$ and C. avium $86^{\top}$, which were respectively 489 and 499 bp in length. Bootstrap values (\%) are indicated at nodes. Bar, $10 \%$ sequence divergence. 
Table 1. Differentiating characteristics between the novel strains and recognized members of the genus Campylobacter

Taxa: 1, Campylobacter volucris sp. nov. ( $n=3) ; 2$, C. coli; 3, C. insulaenigrae; 4, C. jejuni (merged data for C. jejuni subsp. jejuni and C. jejuni subsp. doylei); 5, C. lari subsp. concheus; 6, C. lari subsp. lari; 7, C. peloridis; 8, C. subantarcticus. Data for reference taxa were taken from the original descriptions (Foster et al., 2004; Debruyne et al., 2009, 2010) and from Logan et al. (2000), On et al. (1996, 1998) and Vandamme et al. (1991) and unpublished data of one of the authors (S. L.W. O.). +, Positive; w, weakly positive; (+), 68-95\% strains positive; v, 34-67\% strains positive; $(-), 5-33 \%$ strains positive; -, negative; NA, no data available. All taxa are positive for oxidase production.

\begin{tabular}{|c|c|c|c|c|c|c|c|c|}
\hline Characteristic & 1 & 2 & 3 & 4 & 5 & 6 & 7 & 8 \\
\hline Hippurate hydrolysis & - & - & - & $(+)$ & - & - & - & - \\
\hline Nitrate reduction & + & + & - & $\mathrm{V}$ & NA & + & NA & + \\
\hline \multicolumn{9}{|l|}{ Growth at/on: } \\
\hline $42{ }^{\circ} \mathrm{C}$ & + & + & - & $\mathrm{V}$ & + & + & + & + \\
\hline Nutrient agar & - & + & $\mathrm{V}$ & + & + & $(-)$ & + & - \\
\hline \multicolumn{9}{|l|}{ Growth in presence of: } \\
\hline $\mathrm{NaCl}(2 \%)$ & - & - & - & - & + & $\mathrm{V}$ & $(+)$ & + \\
\hline Glycine (1\%) & - & $(+)$ & - & $\mathrm{V}$ & $(+)$ & + & + & + \\
\hline Safranin $(0.02 \%)$ & - & + & $(-)$ & $\mathrm{V}$ & - & + & - & - \\
\hline Sodium deoxycholate $(0.1 \%)$ & $\mathrm{w}$ & + & - & $\mathrm{V}$ & $\mathrm{V}$ & + & $\mathrm{V}$ & - \\
\hline Cefoperazone (64 $\mathrm{mg} \mathrm{ml}^{-1}$ ) & - & + & + & $\mathrm{v}$ & NA & + & NA & - \\
\hline DNA G + C content $(\mathrm{mol} \%)$ & 29 & $30-33$ & NA & $30-33$ & 30 & $30-32$ & 29 & 30 \\
\hline
\end{tabular}

Reciprocal experiments were performed for every pair of strains and standard deviations ranged from $0.5-16.8 \%$. DNA-DNA hybridization values between strain LMG $24380^{\mathrm{T}}$ and C. lari subsp. lari LMG $8846^{\mathrm{T}}$, C. lari subsp. concheus LMG $21009^{\mathrm{T}}$, C. peloridis LMG $23910^{\mathrm{T}}$, C. subantarcticus LMG $24377^{\mathrm{T}}$, C. jejuni subsp. jejuni LMG $8841^{\mathrm{T}}$, C. coli LMG $6440^{\mathrm{T}}$ and C. insulaenigrae LMG $22716^{\mathrm{T}}$ were respectively $40,41,37,30,24,15$ and $43 \%$. All these values are well below the threshold of $70 \%$ recommended for species delineation (Stackebrandt \& Goebel, 1994).

The present study demonstrates that the three isolates from black-headed gulls obtained during a sampling campaign in Malmö, southern Sweden, in March 1999 represent a novel species within the genus Campylobacter which can be distinguished from other Campylobacter species by AFLP fingerprinting (Supplementary Fig. S1), hsp60 gene sequence analysis (Fig. 2), whole-cell protein electrophoresis (Supplementary Fig. S2) and biochemical characteristics. We propose to classify these strains as Campylobacter volucris sp. nov.

\section{Description of Campylobacter volucris sp. nov.}

Campylobacter volucris (vo.lu'cris. L. gen. n. volucris of a bird).

Cells are Gram-negative, non-spore-forming, curved rods. Single polar flagella are observed. All known strains produce oxidase and catalase and reduce nitrate and selenite. Indoxyl acetate and hippurate are not hydrolysed. Hydrogen sulphide is not produced in triple-sugar iron agar. Alkaline phosphatase-negative. After 3 days of incubation, growth is obtained on blood agar at $37{ }^{\circ} \mathrm{C}$ under microaerobic and anaerobic conditions (where growth may be scanty), but not under aerobic conditions. Strains grow at $42{ }^{\circ} \mathrm{C}$ but not at $25^{\circ} \mathrm{C}$ or at room temperature $\left(18-22{ }^{\circ} \mathrm{C}\right)$. Strains grow on blood agar medium containing $32 \mathrm{mg}$ nalidixic acid, $32 \mathrm{mg}$ cephalothin, $4 \mathrm{mg}$ metronidazole and $32 \mathrm{mg}$ carbenicillin $\mathrm{ml}^{-1}$. Strains grow weakly on MacConkey and potato starch agar media and on media containing $0.1 \%$ sodium fluoride, $0.1 \%$ sodium deoxycholate, $1.0 \%$ ox bile and $0.032 \%$ methyl orange. Strains do not grow on $0.04 \%$ triphenyltetrazolium chloride (TTC) medium and, subsequently, reduction of this agent is not observed. No growth on unsupplemented nutrient agar, on a minimal medium or on casein, lecithin or tyrosine media. No growth is observed on media containing $2.0 \% \mathrm{NaCl}, 1.0 \%$ glycine, $0.02 \%$ safranin, $0.001 \%$ sodium arsenite, $0.1 \%$ potassium permanganate, $0.005 \%$ basic fuchsin, $0.0005 \%$ crystal violet, $0.1 \%$ janus green, $0.02 \%$ pyronin or $64 \mathrm{mg}$ cefoperazone $\mathrm{ml}^{-1}$. Pathogenicity unknown. Strains have been recovered from black-headed gulls (Larus ridibundus) in southern Sweden.

The type strain is LMG $24380^{\mathrm{T}}$ (=CCUG $57498^{\mathrm{T}}$ ), which was isolated from a rectal swab from a black-headed gull in 
March 1999. Strains LMG 24379 and LMG 24381, isolated from other individuals of the same species during the same sampling campaign, are reference strains of the species.

\section{Acknowledgements}

We thank Jean Euzéby for help in naming the novel species. P.V. and L.D. are indebted to the Fund for Scientific Research Flanders (Belgium) for financial support. We thank Evie De Brandt for excellent technical support.

\section{References}

Broman, T., Palmgren, H., Bergstrom, S., Sellin, M., Waldenstrom, J., Danielsson-Tham, M. L. \& Olsen, B. (2002). Campylobacter jejuni in black-headed gulls (Larus ridibundus): prevalence, genotypes, and influence on C. jejuni epidemiology. J Clin Microbiol 40, 45944602.

Broman, T., Waldenstrom, J., Dahlgren, D., Carlsson, I., Eliasson, I. \& Olsen, B. (2004). Diversities and similarities in PFGE profiles of Campylobacter jejuni isolated from migrating birds and humans. J Appl Microbiol 96, 834-843.

Colles, F. M., McCarthy, N. D., Howe, J. C., Devereux, C. L., Gosler, A. G. \& Maiden, M. C. (2009). Dynamics of Campylobacter colonization of a natural host, Sturnus vulgaris (European starling). Environ Microbiol 11, 258-267.

Debruyne, L., Gevers, D. \& Vandamme, P. (2008). Taxonomy of the family Campylobacteraceae. In Campylobacter, pp. 3-26. Edited by I. Nachamkin, C. M. Szymanski \& M. J. Blaser. Washington, DC: American Society for Microbiology.

Debruyne, L., On, S. L. W., De Brandt, E. \& Vandamme, P. (2009). Novel Campylobacter lari-like bacteria from humans and molluscs: description of Campylobacter peloridis sp. nov., Campylobacter lari subsp. concheus subsp. nov. and Campylobacter lari subsp. lari subsp. nov. Int J Syst Evol Microbiol 59, 1126-1132.

Debruyne, L., Broman, T., Bergström, S., Olsen, B., On, S. L. W. \& Vandamme, P. (2010). Campylobacter subantarcticus sp. nov., isolated from birds in the sub-Antarctic region. Int J Syst Evol Microbiol 60, 815-819.

Ezaki, T., Hashimoto, Y. \& Yabuuchi, E. (1989). Fluorometric deoxyribonucleic acid-deoxyribonucleic acid hybridization in microdilution wells as an alternative to membrane filter hybridization in which radioisotopes are used to determine genetic relatedness among bacterial strains. Int J Syst Bacteriol 39, 224-229.

Fermer, C. \& Engvall, E. O. (1999). Specific PCR identification and differentiation of the thermophilic campylobacters, Campylobacter jejuni, C. coli, C. lari, and C. upsaliensis. J Clin Microbiol 37, 33703373.

Foster, G., Holmes, B., Steigerwalt, A. G., Lawson, P. A., Thorne, P., Byrer, D. E., Ross, H. M., Xerry, J., Thompson, P. M. \& Collins, M. D. (2004). Campylobacter insulaenigrae sp. nov., isolated from marine mammals. Int J Syst Evol Microbiol 54, 2369-2373.

French, N. P., Midwinter, A., Holland, B., Collins-Emerson, J., Pattison, R., Colles, F. \& Carter, P. (2009). Molecular epidemiology of Campylobacter jejuni isolates from wild-bird fecal material in children's playgrounds. Appl Environ Microbiol 75, 779-783.

Inglis, G. D., Hoar, B. M., Whiteside, D. P. \& Morck, D. W. (2007). Campylobacter canadensis sp. nov., from captive whooping cranes in Canada. Int J Syst Evol Microbiol 57, 2636-2644.

Kärenlampi, R. I., Tolvanen, T. P. \& Hanninen, M. L. (2004). Phylogenetic analysis and PCR-restriction fragment length polymorphism identification of Campylobacter species based on partial groEL gene sequences. J Clin Microbiol 42, 5731-5738.

Logan, J. M. J., Burnens, A., Linton, D., Lawson, A. J. \& Stanley, J. (2000). Campylobacter lanienae sp. nov., a new species isolated from workers in an abattoir. Int J Syst Evol Microbiol 50, 865-872.

Mesbah, M. \& Whitman, W. B. (1989). Measurement of deoxyguanosine/thymidine ratios in complex mixtures by high-performance liquid chromatography for determination of the mole percentage guanine + cytosine of DNA. J Chromatogr 479, 297-306.

On, S. L. W., Holmes, B. \& Sackin, M. J. (1996). A probability matrix for the identification of campylobacters, helicobacters and allied taxa. J Appl Bacteriol 81, 425-432.

On, S. L. W., Atabay, H. I., Corry, J. E. L., Harrington, C. S. \& Vandamme, P. (1998). Emended description of Campylobacter sputorum and revision of its infrasubspecific (biovar) divisions, including C. sputorum biovar paraureolyticus, a urease-producing variant from cattle and humans. Int J Syst Bacteriol 48, 195-206.

Palmgren, H., Broman, T., Waldenstrom, J., Lindberg, P., Aspan, A. \& Olsen, B. (2004). Salmonella Amager, Campylobacter jejuni, and urease-positive thermophilic Campylobacter found in free-flying peregrine falcons (Falco peregrinus) in Sweden. $J$ Wildl Dis 40, 583587.

Petersen, L., Nielsen, E. M., Engberg, J., On, S. L. \& Dietz, H. H. (2001). Comparison of genotypes and serotypes of Campylobacter jejuni isolated from Danish wild mammals and birds and from broiler flocks and humans. Appl Environ Microbiol 67, 3115-3121.

Pitcher, D. G., Saunders, N. A. \& Owen, R. J. (1989). Rapid extraction of bacterial genomic DNA with guanidium thiocyanate. Lett Appl Microbiol 8, 151-156.

Pot, B., Vandamme, P. \& Kersters, K. (1994). Analysis of electrophoretic whole-organism protein fingerprints. In Chemical Methods in Prokaryotic Systematics, pp. 493-521. Edited by M. Goodfellow \& A. G. O’Donnell. Chichester: Wiley.

Rossi, M., Debruyne, L., Zanoni, R. G., Manfreda, G., Revez, J. \& Vandamme, P. (2009). Campylobacter avium sp. nov., a hippuratepositive species isolated from poultry. Int J Syst Evol Microbiol 59, 2364-2369.

Saitou, N. \& Nei, M. (1987). The neighbor-joining method: a new method for reconstructing phylogenetic trees. Mol Biol Evol 4, 406425.

Sebald, M. \& Véron, M. (1963 ). Base DNA content and classification of vibrios. Ann Inst Pasteur (Paris) 105, 897-910.

Stackebrandt, E. \& Goebel, B. M. (1994). Taxonomic note: a place for DNA-DNA reassociation and $16 \mathrm{~S}$ rRNA sequence analysis in the present species definition in bacteriology. Int J Syst Bacteriol 44, 846849.

Thompson, J. D., Gibson, T. J., Plewniak, F., Jeanmougin, F. \& Higgins, D. G. (1997). The CLUSTAL_X windows interface: flexible strategies for multiple sequence alignment aided by quality analysis tools. Nucleic Acids Res 25, 4876-4882.

Vandamme, P., Pot, B., Falsen, E., Kersters, K. \& De Ley, J. (1990). Intra- and interspecific relationships of veterinary campylobacters revealed by numerical analysis of electrophoretic protein profiles and DNA : DNA hybridizations. Syst Appl Microbiol 13, 295-303.

Vandamme, P., Falsen, E., Rossau, R., Hoste, B., Segers, P., Tytgat, P. \& De Ley, J. (1991). Revision of Campylobacter, Helicobacter and Wolinella taxonomy: emendation of generic descriptions and proposal of Arcobacter gen. nov. Int J Syst Bacteriol 41, 88-103.

Vandamme, P., Van Doorn, L.-J., al Rashid, S. T., Quint, W. G. V., van der Plas, J., Chan, V. L. \& On, S. L. W. (1997). Campylobacter hyoilei Alderton et al. 1995 and Campylobacter coli Véron and Chatelain 1973 are subjective synonyms. Int J Syst Bacteriol 47, 1055-1060. 
Vandamme, P., Holmes, B., Bercovier, H. \& Coenye, T. (2006). Classification of Centers for Disease Control Group Eugonic Fermenter (EF)-4a and EF-4b as Neisseria animaloris sp. nov. and Neisseria zoodegmatis sp. nov., respectively. Int J Syst Evol Microbiol 56, 1801-1805.

Waldenström, J., Broman, T., Carlsson, I., Hasselquist, D. Achterberg, R. P., Wagenaar, J. A. \& Olsen, B. (2002). Prevalence of Campylobacter jejuni, Campylobacter lari, and Campylobacter coli in different ecological guilds and taxa of migrating birds. Appl Environ Microbiol 68, 5911-5917.

Waldenström, J., On, S. L., Ottvall, R., Hasselquist, D. \& Olsen, B. (2007). Species diversity of campylobacteria in a wild bird community in Sweden. J Appl Microbiol 102, 424-432.

Zanoni, R. G., Debruyne, L., Rossi, M., Revez, J. \& Vandamme, P. (2009). Campylobacter cuniculorum sp. nov., from rabbits. Int J Syst Evol Microbiol 59, 1666-1671. 